\title{
Ecological Quality Improvement of Urban Landscapes with Emphasis on Sustainable Development Principles Case Study: River of Darabad Valley, Tehran, Iran
}

\author{
Ferial Ahmadi ${ }^{1}$, Ali Reza Sadeghi ${ }^{2 *}$, Ali Reza Eskandarinezhad ${ }^{3}$
}

\begin{abstract}
Sustainable development is known as a process that pave the way for achieving pleasant ecological quality in urban landscape. In fact, it seems that sustainable development principles and evaluation of the natural context should be the fundamental part in the process of improvement of the quality of urban landscape. The present research has been conducted in order to preserve and manage Tehran's River of Darabad Valley landscape as a living, dynamic ecosystem; moreover, to improve the ecological quality of the riverbed through the implementation of sustainable development principles.

Process recommendations to improve the ecological quality of the River of Darabad Valley through sustainable development are based on descriptive analysis of library research and case study, as well as observation procedures with survey studies. Recommendations have been based on the study and analysis of multiple primary factors, including environmental, cultural, physical, and social features. Subsequent suggestions for designing a sustainable landscape have been provided, and have been focused on repair and protection of the landscape, and ecological and aesthetic principles. Emphasis has been placed on protection and improvement of the natural landscape and the diverse bionetwork of the region, the removal of inappropriate applications and bio- environmental pollutants, and better rehabilitation and restoration of the context of valley's river, as a human real and public space. Suggestions are in accordance with the natural limits of the river; serving to both protect the natural landscape of the river, and provide visitors with outdoor recreational experiences and areas, as well as welfare facilities.
\end{abstract}

Key Words: Ecological quality, sustainable development principles, River of Darabad V alley

\section{Introduction}

Beautiful natural manifestations such as rivers, mountains, bushes and like that can be in circulation across city structures and embody life in cities are left without any plan. They can function not only as urban signs but also in an alive and dynamic ecosystem framework. They can equilibrate the ecological and bio- environmental structure of cities and transform to visitors' memories. Memories that result in formulation of citizen' identities and are considered as an important factor in knowing city.

In recent years, urbanization has always experienced ever increasing growth. In that, the last decades of the past century witnessed 100\% increase in urban population,

1 Assistant Professor of Landscape Architecture, Department of Architecture, University of Mazandaran. $2^{2 *}$ (Corresponding Author): Assistant Professor of Urban Design, Department of Urban Planning \& Design, Faculty of Art and Architecture, Shiraz University

${ }^{3}$ Ali Reza Eskandarinezhad: PhD Candidate of Civil Engineering, Faculty of Engineering, Shiraz University. 
comprising about $45 \%$ of the world population. Besides advantages such as accessibility to clean water, hygiene, and so like, the negative effects of urbanization on environment, especially degradation and pollution of urban environment, cannot be ignored. Changes in the climate, reduction in biodiversity and increased pollution, largely caused by the growth of technology taking place without consideration to the environment, are contributing to the destruction of the Earth's natural heritage. A lack of logical interaction between the city and the natural world combined with poorly designed technology and infrastructure is resulting in a degradation of the ecological quality of the environment and ultimately the standard of human life.

In fact, due the reduction of ecologically valuable natural landscapes and regions inside urban areas, which taken as important parts of urban landscape, several environmental issues have been emerged. To decrease environmental issues of today's cities and reduce negative impacts of urbanization on urban environment, stronger presence of nature and natural elements in urban landscape (as the environment and container of human activities) and enrichment of experiences in understanding natural elements of urban landscape are necessary for citizens. Since, urban landscape is comprised of natural and human-made environments which always provide the ground for human activities. Therefore, human activities are affecting and affected by natural and man-made urban landscape. In effect, analysis and assessment of ecological qualities of urban landscape through understanding, investigation, and analysis of mosaic patterns and structures, allow for improving ecological values of urban landscape, which finally contribute to preservation of these landscapes for future generations. It is evident that using sustainable development principles in designing urban landscapes, sympathetic to the needs of living beings, together with high quality natural resources, benefit not only the environment but the welfare and satisfaction of citizens. In fact, sustainable development principles and evaluation of the natural context should be the fundamental part in the process of improvement of the quality of urban landscape. The present research has been conducted in order to preserve and manage Tehran's River of Darabad Valley landscape as a living, dynamic ecosystem; moreover, to improve the ecological quality of the riverbed through the implementation of sustainable development principles. Process for improving the ecological quality of the River of Darabad Valley through sustainable development is based on descriptive analysis of library research and case study, as well as observation procedures with survey studies.

\section{River Valleys in Urban Landscape}

There are two standpoints with respect to human's relationship with urban landscape. In one of them, human always ignored his evolutionary history, the way cities formed, and the necessity for maintaining urban landscape. In contrast, from the other perspective, human is aware of his past and unity with everything and all living creatures. Based on the latter, human wisely respect urban landscape and seeks his creative role in this context. With respect to the second point of view, ecology of urban landscape is the study and use of information related to natural patterns and processes of the context and the way it is connected to material world and living creatures (human and other living organisms) in different scales. 
However, certainly one of the most important embodiments of environment (whether natural or man-made) in human's residences is urban landscape, particularly in terms of natural urban landscape and its elements causes aesthetic values move from art galleries and architectural single buildings to natural forms and large-scale artificial environments. In urban landscape, visual elements contain a set of elements which in different contexts show the capabilities of an area's landscape, making the set's landscape legible, improving its quality, and giving it a special position in people's mental map in order to help orient and direct the set itself. These elements include: signs and symbols, environmental qualities, visual qualities, gateways, public realms and spaces, edges, and directions. Environmental qualities mean special natural traits such as hills, elevations, natural slope of the earth, trees and ecological areas, streams and rivers, valleys, landscapes, plantation, and specific topography, characteristics which are called natural urban landscape in this article. In fact for a comfortable life, mankind needs a pleasant urban landscape. Valleys are called as one of the main elements of natural urban landscape. Combination of natural elements of water, soil, rocks, and plants with each other and in various artistic forms in valleys (especially in the valleys of Tehran) reminds of the manifestation of basic nature, giving a special calmness to human.

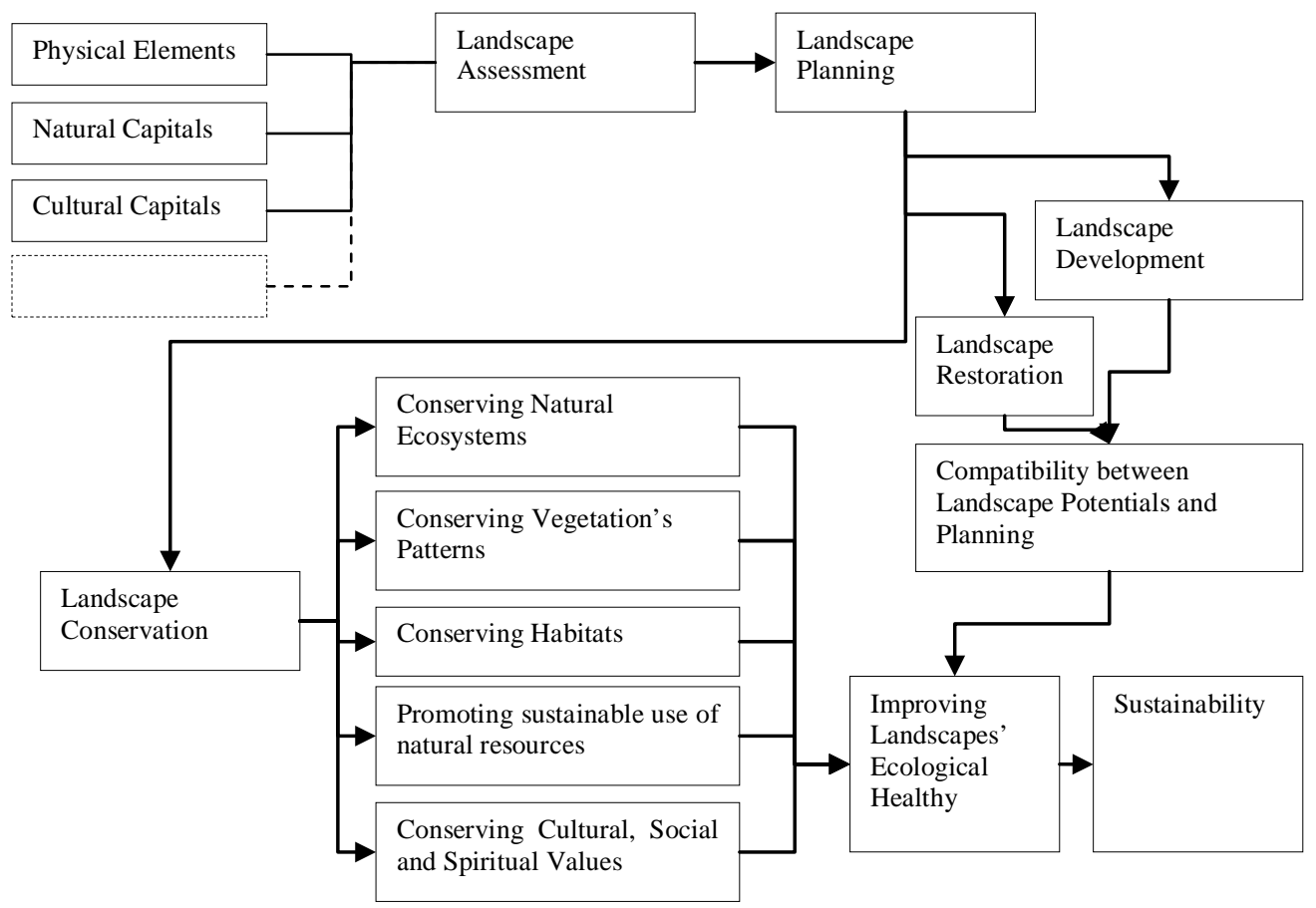

Fig1: Urban Landscape Sustainability Source: the authors

\section{Sustainable Development Principles in Urban Landscape}

Landscape, which includes topography, vegetation and associated plants and soil, water bodies, and their spatial configuration, is one of the most visual needs by 
people. Human-nature interactions lead human beings to have contrasting preference on the surrounding landscape and environment because a pleasing landscape can bring mental and physical benefits to people (Kaplan \& Kaplan, 1989). It should be noted that landscapes evolve continuously in a more or less chaotic way and reflect social and economic needs of a particular society at a given moment. History records not only gradual changes in the landscape, but many sudden and complete transformations caused by natural disturbance and human action (Antrop, 2004). Therefore, Humans form and change landscapes because of economic, social or ecological purposes (Linehan \& Gross, 1998).

The term of sustainability was first used in 1980 in IUCN's World Conservation Strategy. The definition approved by the United Nation Food and Agricultural Organization Council in 1988 (Botequilha leitao \& Ahern, 2002). Therefore, Sustainable development is a widely accepted strategic framework in decision-making about the future use of land (IUCN, 1992). In fact, sustainable development is generally considered to be at the intersection of environment, economy, and society, although these terms are now often expanded into phrases reflecting ecosystem services and limits, fair and durable prosperity, and health and social justice (Selman, 2008).

It should be mentioned that sustainability is the handling and conservation of natural resources and the orientation of technological and institutional changes do as to ensure the continuous satisfaction of human needs for present and future generation (Cena, 1999). The idea of sustainability can be interpreted in two ways. First, the idea can refer to the conservation of certain landscape types or values and implicitly the continuation of practices that maintain and organize these landscapes. Second, the idea might refer to sustainability as a main principle for future landscaping (Antrop, 2006). For abovementioned Sustainable landscape development requires that landscape planning aims for a condition of stability in physical and social systems achieved by accommodating the needs of the present without compromising the ability of future generations to meet their needs (Ahern, 2002). Hence, sustainable development of landscapes demands that: the landscape structure supports the ecological, social and economic processes required, so it can deliver its goods and services to present and future generations; the landscape can change over time without losing its key resources; stakeholders are involved in decision-making about landscape functions and patterns (Opdam, Steingr"over, \& van Rooij, 2006).(Fig1) 


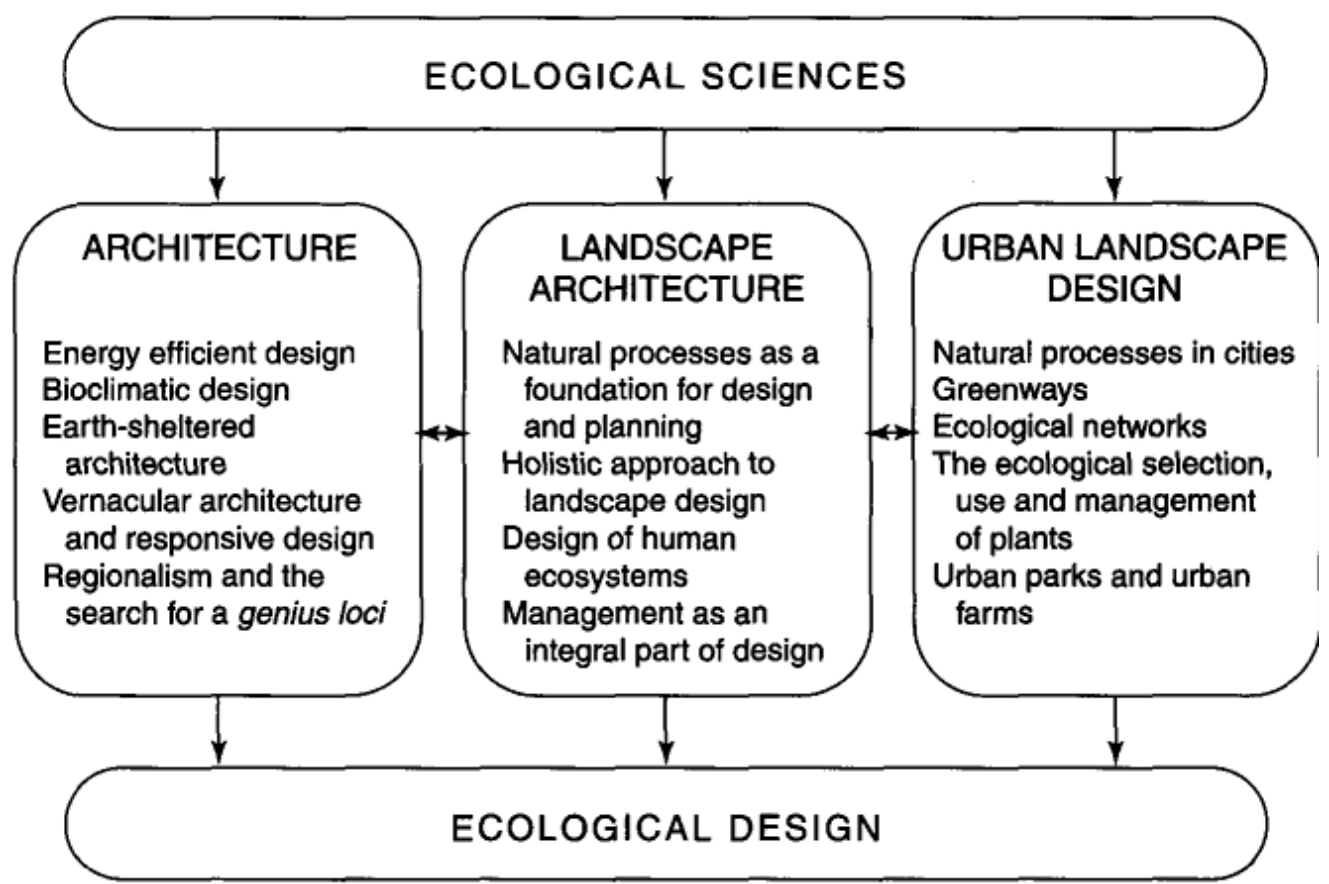

Fig2: the interface of ecology with architecture, landscape architecture and urban landscape design Source: (Makhroumi \& Pungetti, 1999).

\section{Ecological Quality Improvement through Ecological Design}

Ecology is study of the distribution of microorganism of group's organism in an environment and often is misunderstood with natural environment or oriented environment (Dadson, Allen, \& Dodson, 1998). The goal of ecological research is to understand how the environment, including biotic and abiotic patterns and processes, affects the abundance and distribution of organisms (A.Wiens \& R.Moss, 2005) In 100 years since its inception, has increasingly provided the scientific foundation for understanding natural processes, managing environmental resources and achieving sustainable development. By the 1960s, ecology's association with the environmental movement popularized the science and introduced it to the design profession (Makhzoumi, 2000). Afterwards,, Ecological design defined as utilizes of principles of ecological design for built environmental design and life style. So that they to be integrated safe and appropriate to the nature including of biosphere (Feizi, Ahmadi, \& Ahmadi, 2014). (Fig2) 


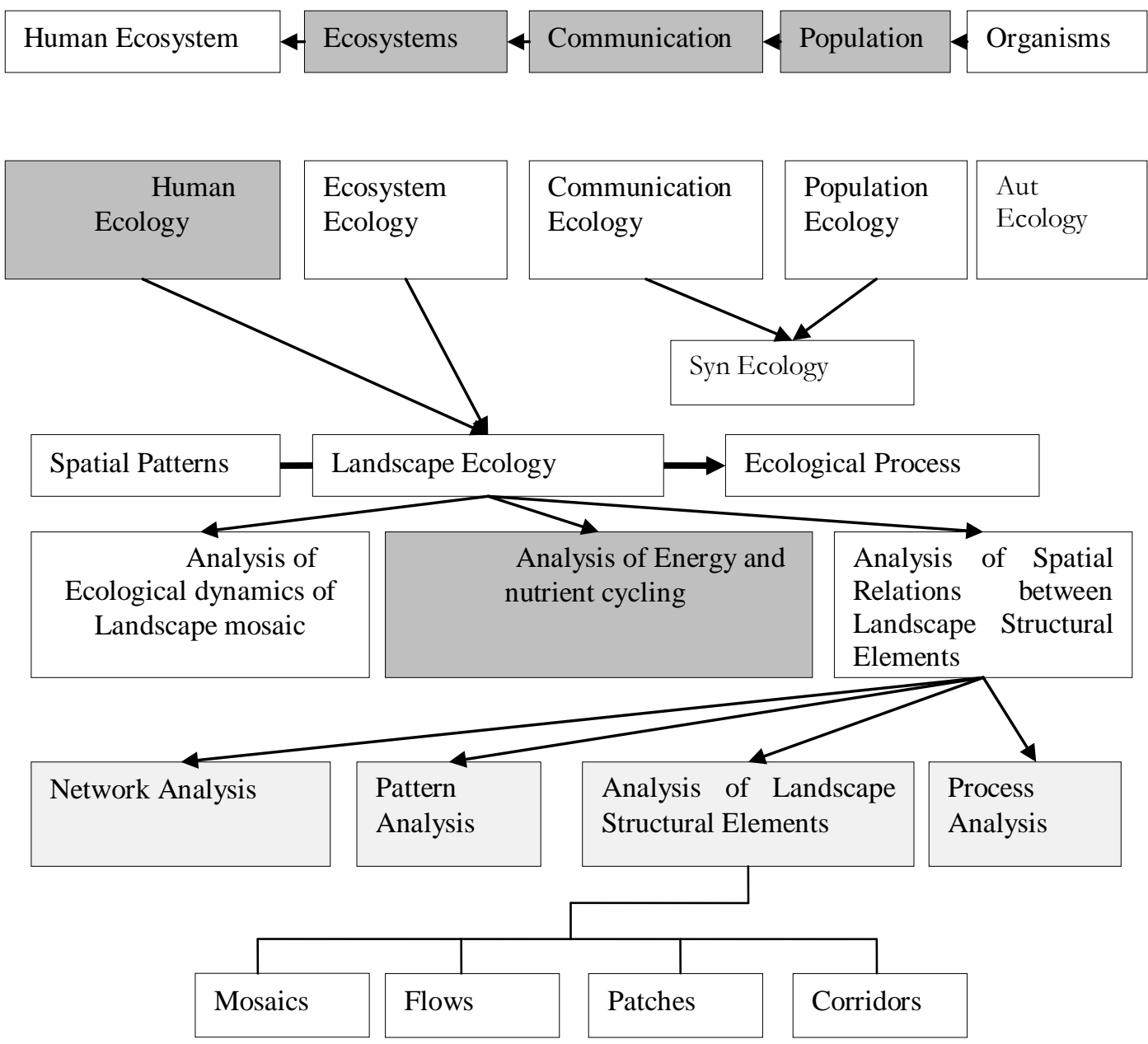

Fig3: Landscape Ecology Source: the authors

In addition, Landscape ecology that has been defined as the study of the effect of pattern on process, where pattern refers specifically to landscape structure (Turner, 1989), is a branch of modern ecology that deals with the interrelationships between man and his open and built-up landscapes (Forman \& Godren, 1986). As a highly interdisciplinary science in systems ecology, landscape ecology integrates biophysical and analytical approaches with humanistic and holistic perspectives across the natural sciences and social sciences (Forman, 1995). To summarize, landscape ecology has the potential of forming the scientific foundation for a comprehensive understanding of the landscape. Its concern with linkages between resources, human use and the patterns they create on the land has much in common with the concerns of landscape architecture, landscape planning and management (Makhzoumi \& Pungetti, 1999). (Fig3)

Ecological landscape design integrates input from landscape ecology and design, both of which are seen as providing parallel and complementary, albeit different methodological 
approaches (Makhzoumi \& Pungetti, 1999). Ecological landscape design is based on a holistic understanding of landscape, which encourages a dynamic and responsive approach. It is holistic because it simultaneously considers past and present as well as local and regional landscape patterns and processes. It is responsive because it develops from a realization of the constraints and opportunities of context whether natural, cultural or a combination of both (Makhzoumi, 2000).

\section{Discussion}

\section{Urban Landscape Ecology of Darabad Valley (Tehran)}

Darabad valley context, which has a collared pattern of open spaces and enclosures, is divided to three main patches of mountainous/natural, half-urban/natural, and urban/natural. It is in the context of these 3 major patches that secondary patches, such as organic residential tissues and newly-made residential complexes, gardens and green spaces, riverside vegetation and mountain open green spaces, spaces with healthcare and military uses, are interconnected with routes, pavements, and roads on the axis of Darabad River as the main passage. Analysis of landscape structure in large scale of the area of study and based on geomorphologic characteristics show that in this context there three main categories of mountain, valley, and urbanized landscape. In this division, mountain landscape contain mountains, canyons, Darabad River, rock outcrops, natural attractions such as waterfalls, caves, springs, transient seasonal patches, and diversity of ground shape. Valley landscape is made of rivers and riverside vegetation. In accordance with the ground shape, valley height and body, and the rate of its naturalness, valley landscape is divided into three areas, which are high, fairly-high, and low valleys. Yet in urbanized type of landscape presence of villas and garden houses on mountain slopes shows the change of mountain and valley landscapes to the urban one. Decrease of green space and transformation of gardens and villas to apartments and imbalance and disorder of skyline demonstrates a fully urban landscape. Table 1 analyzes the form of these patches in the natural urban landscape mosaic of Darabad valley. (Table 1)

Table 1. Ecological conditions of the natural urban landscape's mosaic of Darabad Valley. Source: the authors

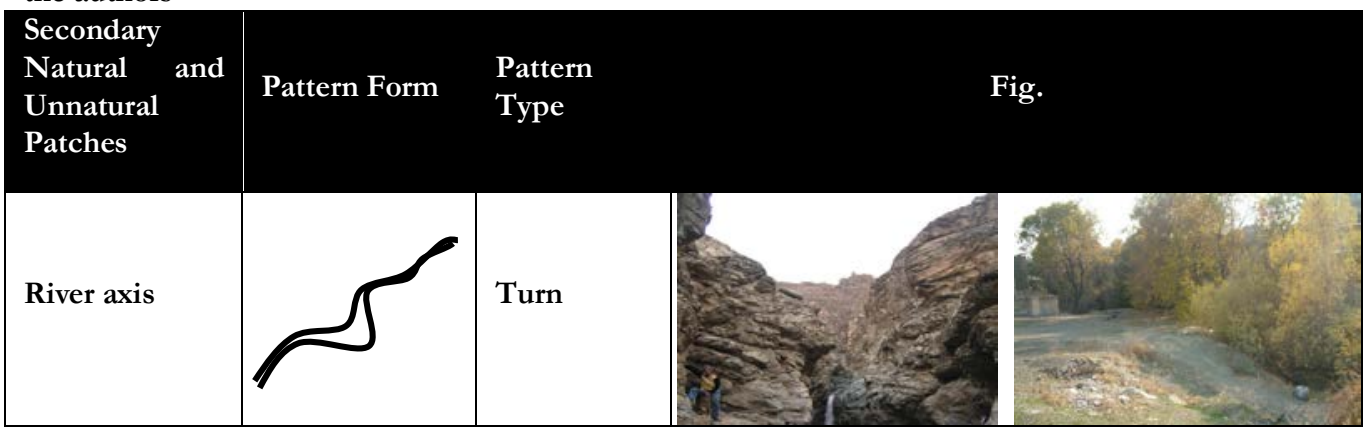




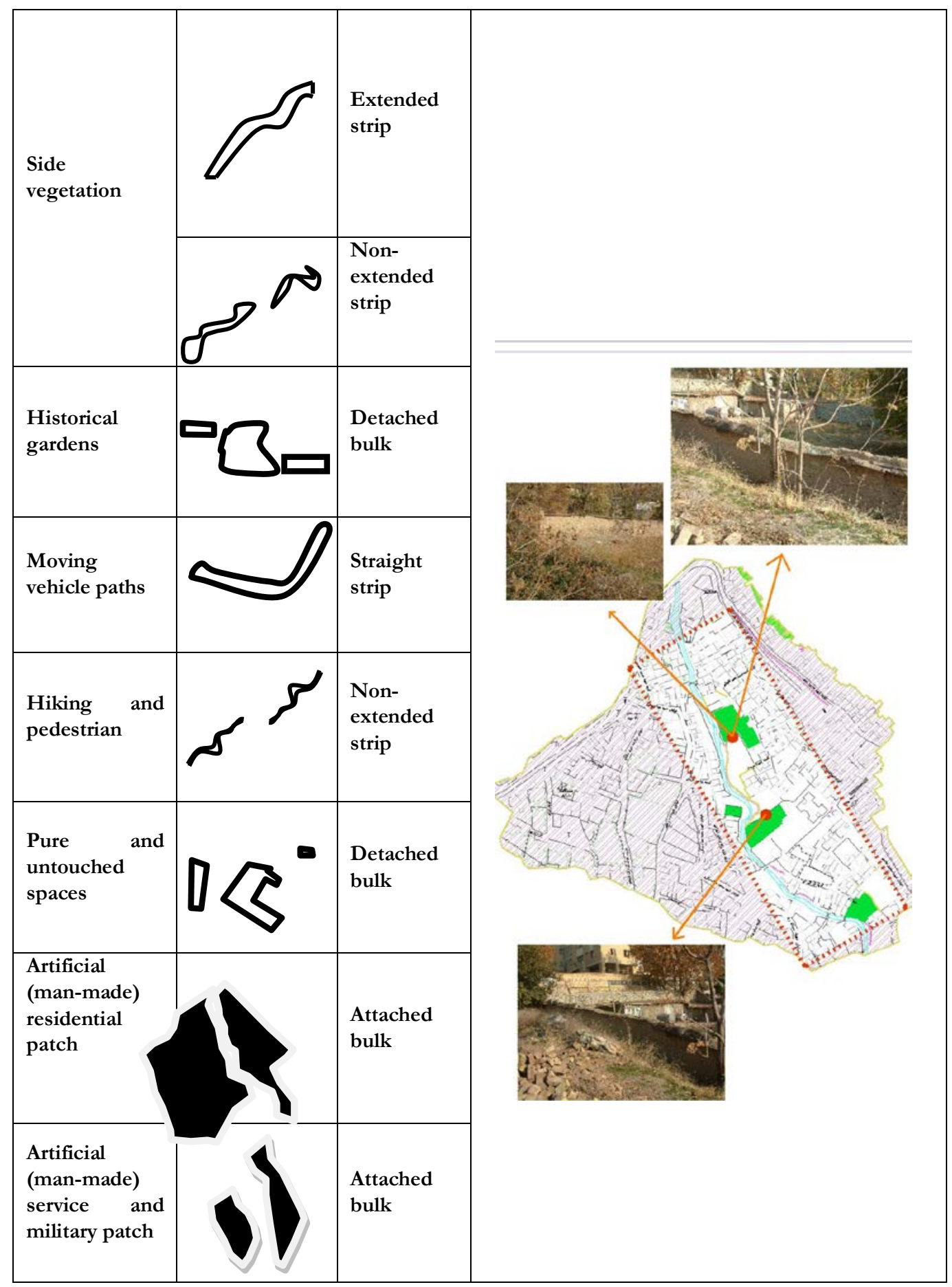




\section{Summary}

The natural bed of the river of Darabad Valley and its natural limits are the best natural potentials of Tehran and if they are organized and rehabilitated according to sustainable development principles, not only it can equilibrate the city bioenvironmentally but also it can provide visitors with spiritual and mental comforts in a public realm and a social, alive and dynamic situation.

With regard to the important fact that ecological quality of this river bed has lost because of the presence of: Severe environmental pollutions and increasing the pollution of river's water; Existence of construction waste beside and inside the river; Advance towards river limits and excessive construction in the southern part without paying attention to the dangers of landslide; liquid from pouring house and hospital sewage and construction waste disposal; Leaving solid and half solid waste into river bed; Changing and destroying landform, plants, environment, and landscape; Increasing; process of destruction and changing of mountainous and valley lands from north to south; Presence of hunters who trap the animals; Turning river to canal and destroying riverside's natural landscape in the southern part; Building insecure walls and foundations, which are inharmonious to the natural landscape, and destroying the natural margin of the river; Existence of glacial and cold climatic conditions in the winter, occurrence of heavy rainfalls and blizzard, and possibility of avalanche and frostbite Weak rock structure, made of tuff, and creation of much sediment in the river bed as a result of erosion; Severe erosion of soil cover and debris in the slopes due to lack of control over surface waters; Average to high water erosion and production of average to high runoff; Natural limitations such as rock outcrops, soil erosion, severe slopes, and low soil depth in some parts of the area under study; Change in animals' eating habits and their tendency to eat the garbage; Low vegetation diversity and their low density in most of the area; Decrease in Darabad River's water discharge since September until mid-autumn; and Low diversity of mammal and amphibian kinds. Approaches for improving ecological quality of the river bed based on sustainable natural landscape principals are presented in table 2.

Table2: Approaches for Ecological Quality Improvement of Darabad Valley with emphasis on Sustainable Development Principles. Source: Authors

\begin{tabular}{|c|c|c|c|}
\hline \multicolumn{2}{|c|}{$\begin{array}{ll}\text { Aspects } & \text { of } \\
\text { sustainability }\end{array}$} & & \multirow[b]{2}{*}{$\begin{array}{l}\text { Approaches } \\
\text { - Controlling the destruction of } \\
\text { natural side of the valley } \\
\text { - Preventing water and soil } \\
\text { pollution within the area of study } \\
\text { Keeping and increasing the } \\
\text { biological diversity in the area of study (with } \\
\text { focus on the birds and specific kinds of } \\
\text { mammals) } \\
\text { Keeping the animals and } \\
\text { increasing the kinds of wild life in the } \\
\text { region as a factor to attract tourists }\end{array}$} \\
\hline $\begin{array}{l}\text { Iviron } \\
\text { ental } \\
\text { staina } \\
\text { ity }\end{array}$ & ctive & $\begin{array}{l}\text { Reducing contamination through } \\
\text { protecting natural bed against all } \\
\text { acoustic, water, air, and optic } \\
\text { pollutions } \\
\text { Protecting biologic diversity, place } \\
\text { of vegetation and animal life of the } \\
\text { region } \\
\text { Protecting the bed against } \\
\text { environmental pollutions (domestic } \\
\text { and industrial wastewater and } \\
\text { wastes, etc) }\end{array}$ & \\
\hline & $\begin{array}{l}\text { Developm } \\
\text { ent \& } \\
\text { mprovem }\end{array}$ & $\begin{array}{l}\text { increasing the bed's ecologic power } \\
\text { and decrease soil erosion } \\
\text { Using proper plant coverage }\end{array}$ & $\begin{array}{l}\text { - Keeping the open views and } \\
\text { preventing the limitation of the view } \\
\text { towards natural and mountainous scenes }\end{array}$ \\
\hline
\end{tabular}




\begin{tabular}{|c|c|c|c|c|}
\hline & ent & $\begin{array}{l}\text { compatil } \\
\text { condition } \\
\text { from e } \\
\text { evaporat } \\
\text { permeab } \\
\text { Omitting } \\
\text { incompa } \\
\text { environn } \\
\text { natural } r \\
\text { of habita } \\
\text { Expandi } \\
\text { educatior } \\
\text { environn } \\
\text { natural b } \\
\text { Compati } \\
\text { developn } \\
\text { with natt } \\
\text { (landscap } \\
\text { performe } \\
\text { natural } 1 \\
\text { the bed.) }\end{array}$ & $\begin{array}{l}\text { with the bed's natural } \\
\text { in order to protect soil } \\
\text { sion, decrease water } \\
\text { h, and increase soil } \\
\text { y } \\
\text { perations and activities } \\
\text { le with natural } \\
\text { ht (hunting in most } \\
\text { ions provides the cause } \\
\text { lisorders. } \\
\text { managerial and } \\
\text { plans in the fields of } \\
\text { ntal conservation and } \\
\text { ity of design and } \\
\text { nt in natural landscapes } \\
\text { l boundaries of the bed } \\
\text { design shall be } \\
\text { in compliance with } \\
\text { undaries and ranges of } \\
\end{array}$ & $\begin{array}{l}\text { Keeping the existing vegetation } \\
\text { and developing it } \\
\text { - } \quad \text { Permeating the vegetation into } \\
\text { the urban tissue of the area of study } \\
\text { - Keeping aged vegetation in the } \\
\text { area of study } \\
\text { - Creating an accessible green } \\
\text { space, capable of being used more, } \\
\text { alongside the valley } \\
\text { - Informing about natural } \\
\text { resources of the river valley by public } \\
\text { educational programs, signs, and symbols } \\
\text { - Protecting and re-improving the } \\
\text { natural features and function of the river } \\
\text { valley } \\
\text { - } \\
\text { participation in order to improve riverside } \\
\text { borders }\end{array}$ \\
\hline \multirow{3}{*}{$\begin{array}{l}\text { Social } \\
\text { sustaina } \\
\text { bility }\end{array}$} & Protective & $\begin{array}{l}\text { Protectin } \\
\text { bed (soc } \\
\text { natural b } \\
\text { protectec }\end{array}$ & $\begin{array}{l}\text { all social values of the } \\
\text { activities performed in } \\
\text { during ages should be }\end{array}$ & $\begin{array}{l}\text { - Establishing pavement on the } \\
\text { river valley side } \\
\text { Establishing green centers for }\end{array}$ \\
\hline & \multirow[t]{2}{*}{$\begin{array}{l}\text { Developm } \\
\text { ent \& } \\
\text { Improvem } \\
\text { ent }\end{array}$} & Tourism & $\begin{array}{l}\text { Developing tourism } \\
\text { within limits of natural } \\
\text { capacity of the region. } \\
\text { Providing facilities and } \\
\text { services required for } \\
\text { tourism including } \\
\text { recreational, security, } \\
\text { and welfare services } \\
\text { and facilities (it is } \\
\text { evident that these } \\
\text { services should be } \\
\text { compatible with } \\
\text { natural resources of } \\
\text { the region). } \\
\text { Providing the ground } \\
\text { for expansive } \\
\text { recreational in } \\
\text { experiences } \\
\text { compliance with local } \\
\text { capacity and power of } \\
\text { landscape in order to } \\
\text { motivate tourists to } \\
\text { frequently appear in } \\
\text { these landscapes }\end{array}$ & $\begin{array}{l}\text { valley Turning Darabad Valley into an } \\
\text { attractive tourism center } \\
\text { section's habitat for a green space on the } \\
\text { river valley's side } \\
\text { - Organizing and maintaining the } \\
\text { upstream drainage } \\
\text { - Keeping the valley's corridor for } \\
\text { air and water flow and sustainability of the } \\
\text { structure and green space } \\
\text { - } \quad \text { Sustainable } \\
\text { regeneration, and recreational usage of } \\
\text { valley's natural resources } \\
\text { - Maintenance and regeneration of } \\
\text { the gardens alongside the valley in the urban } \\
\text { section Keeping unsustainable soils in } \\
\text { - } \quad \text { Avoiding from the construction } \\
\text { sloped sections } \\
\text { - } \\
\text { of skyscrapers alongside the river in order } \\
\text { to secure its extends }\end{array}$ \\
\hline & & $\begin{array}{l}\text { Local } \\
\text { Commu } \\
\text { nities }\end{array}$ & 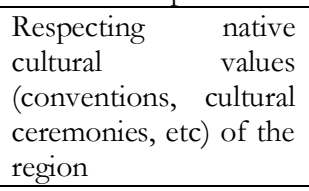 & $\begin{array}{l}\text { - Inserting the nature into } \\
\text { residential sections } \\
\text { - Using the elements, materials, } \\
\text { and local plants when designing the } \\
\text { landscape for harmony with the area's pure }\end{array}$ \\
\hline
\end{tabular}




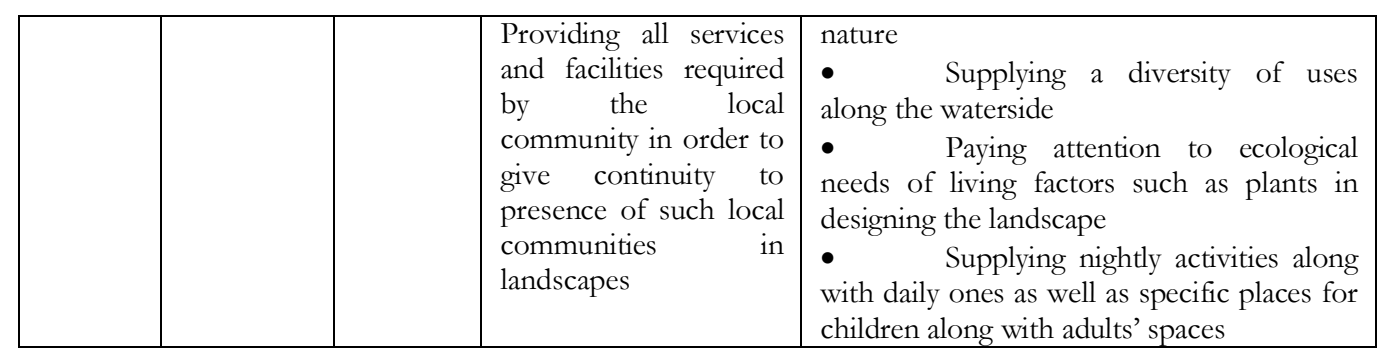

Nowadays mankind witnesses large-scale destruction of natural urban landscapes. Despite nature's ability to reconstruct herself after natural and artificial disturbances in addition to its resistance against the destruction of its ecosystems, factors such as climate change, global warming, excessive exploitation of natural resources, human's greedy interferences in natural urban ecosystems such as forests, rivers, etc. have paved the way for pollution of vital water resources, soil erosion, and the collapse of genetic plant reserves of natural urban landscapes. The disturbance in such landscapes along with their large-scale destruction, happening as a result of human's lack of knowledge to the environment's nature and its within ecosystems, will bring difficulties for the conceptual-perceptual relation between human and nature in urban environments.

Sustainable development is known as a process that pave the way for achieving pleasant ecological quality in urban landscape. In fact, it seems that sustainable development principles and evaluation of the natural context should be the fundamental part in the process of improvement of the quality of urban landscape. In fact, an ecological approach in planning and designing the context, saving and regenerating natural systems, achieving life patterns in the nature strengthens and organizes humans' connection with the nature improves the ecological qualities of main elements in natural urban landscape. According to these, analyzing the ecology of natural urban landscape along with the analysis of valley beds' ecology and that of its surrounding plays a significant role in improving ecological qualities in River valleys.

\section{References}

A.Wiens, J., \& R.Moss, M. (2005). Issues and Perspectives in Landscape Ecology. New York: Cambridge University Press.

Ahern, J. (2002). Greenways as strategic landscape planning: theory and application. Dissertation . Wageningen, Netherlands: Wageningen University.

Antrop, M. (2004). Continuity and change in landscapes. Landscape change and the urbanization process in Europe. Landscape and Urban Planning, 9-26.

Antrop, M. (2006). Sustainable landscapes: contradiction, fiction or utopia? Landscape and Urban Planning, 187-197.

Botequilha leitao, A., \& Ahern, J. (2002). Applyning Landscape Ecological Concepts and Metrics in Sustainable Landscape Planning. Landscape and Urban Planning, 65-93.

Calkins, M. (2005). Strategy use and challenges of ecological. design in landscape architecture ,29-48.

Cena, A. (1999). The farm and rural community as economic systems. In F. Golley, \& J. Bellot, Rural Planning from an Environmental Systems Perspectives (pp. 229-286). New York: Springer.

Dadson, A., Allen, T., \& Dodson, S. (1998). Ecology. New york: University Press Oxford. 
Farina, A. Principles and Methods in Landscape Ecology Towards a Science of Landscape. Netherland: Springer, 2007.

Fernandes,J. Landscape ecology and conservation management Evaluation of alternatives in a highway EIA process. Environmental Impact Assessment Review 20. Pp 665-680, 2000.

Feizi, M., Ahmadi, J., \& Ahmadi, M. (2014). Ecological Design Process, the Way toward Improve Modern Sustainable. Journal of Civil Engineering and Urbanism Architectural Design , 125-130.

Forman, R. (1995). Land Mosaics: The Ecology of Landscapes and Regions. Cambridge : Cambridge University Press.

Forman, R., \& Godren, M. (1986). Landscape Ecology. New York: Wiley and Sons.

IUCN. (1992). The Rio Declaration on the Environment. Rio de Janeiro: IUCN,UNEP,WWF.

Pour Jafar M. R. Elements of Water, Soil, and Plant in Nature; Case of Study: Darabad River Valley, Harmony of Natural Elements, Farhangestan Honar Publication: Tehran, 2004. [In Persian]

Pour Jafar M. R., Ahmadi F., and Sadeghi A. Expansion of Principles and Criteria of Sustainable Landscape Designing in Restoring Natural Landscape of Dried Watercourse in Shiraz, Scientific-Research Journal of Environmental Sciences, 28, 2010. [In Persian]

Kaplan, R., \& Kaplan, S. (1989). The Experience of Nature. Cambridge: Cambridge University Press.

Linehan, J., \& Gross, M. (1998). Back to the future, back to basics: the social ecology of landscapes and the future of landscape plannig. Landscape Urban Planning , 207-224.

Makhzoumi, J. (2000). Landscape ecology as a foundation for landscape architecture: application in Malta. Landscape and Urban Planning, 167-177.

Makhzoumi, J., \& Pungetti, G. (1999). Ecological Landscape Design and Planning: The Mediterranean Context. London: E \& FN Spon.

Opdam, P., Steingr" over, E., \& van Rooij, S. (2006). Ecological networks: A spatial concept for multi-actor planning of sustainable landscapes. Landscape and Urban Planning, 322-332.

Selman, P. (2008). What do we mean by sustainable landscape? Sustainability: Science, Practice, \& Policy, 23-28.

Turner, M. (1989). Landscape ecology: the effect of pattern on process. Annual Review of Ecology and Systematics , 171-197. 